\title{
RE-Discovering Utricularia PLATENSIS SPEg. In ARgENTINA
}

\section{DANEL ARANOA • Buenos Aires • Argentina • danelaranoa@gmail.com}

In 2017, my girlfriend and I were part of the AAPC (Argentine Association of Carnivorous Plants). Within the framework of said institution, which sought to popularize knowledge about these plants and advocate for their protection, several on-site investigations were carried out to register specimens in their habitat.

The only native carnivorous plant of which we had knowledge in the province of Buenos Aires was Utricularia gibba L. (Lentibulariaceae) at a few locations. However, there was a particularly elusive species, whose most recent description in the literature was from Peter Taylor's Utricularia monograph: U. platensis Speg. (Taylor 1989). The last records we could find of this species for Argentina were made by Dawson (1965) and also reports from the Biodiversity Information System (Zuloaga 1996).

Dawson described U. platensis as a "common aquatic species in calm waters of Buenos Aires." However, in the intervening decades there has been significant human development in this region, both urban and rural. We could only presume that it still occurred somewhere in the vicinities of Buenos Aires, so we decided to explore, in an attempt to re-discover this rare species.

\section{The location}

Argentina is geographically divided into six major regions: Northwest (NOA), Northeast (NEA), Cuyana or del Cuyo Region, Patagonia, and North and South Pampean Plains (Ministerio de Ciencia 2016). In these regions, characteristic relief changes can be found that determine smaller areas with their own geographic, climatic and water properties, known as subregions. The findings described below were made in the subregion of the "humid pampa" or "depressed pampa" that covers most of the central-eastern province of Buenos Aires (Fig. 1). It is characterized by its wide plains and grasslands, abundant quantity of streams, channels, lagoons, and the basins of the Salado and Samborombón rivers. Due to its depressed and flat relief and the scarce runoff from its soils, the humid pampas present large floodplains in the rainy season (Velázquez et al. 2014; World Wildlife Fund 2021). According to the inventory of wetlands carried out by the Provincial Directorate of Natural Resources in 2019, the water in this subregion comes from rainfall, groundwater, and surface runoff (Mulvany et al. 2019).

Among the wetlands present in the province, one of the most important (due to its size, biodiversity, and popularity as a tourist attraction) is the one comprised (from North to South) of the interconnected lagoons of Vitel, Chascomús,

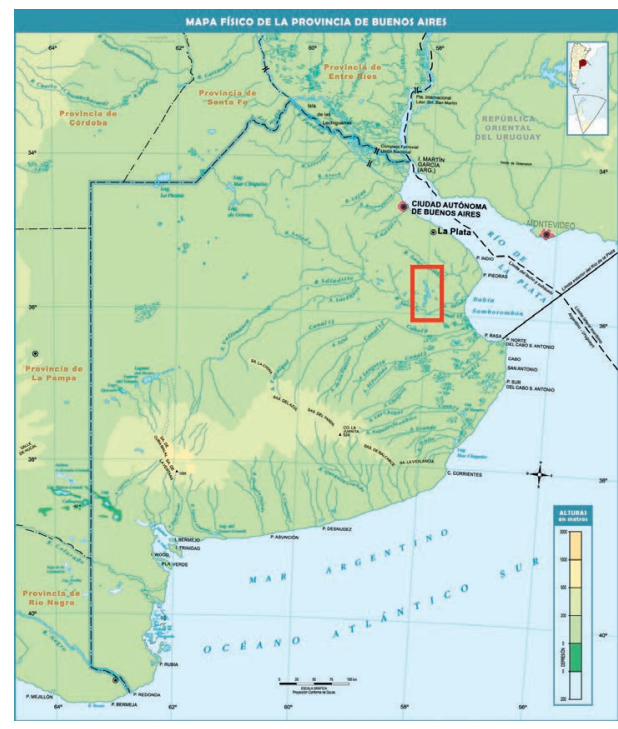

Figure 1: Chascomús lagoon area (red box) within the central-eastern province of Buenos Aires, Argentina. 
Adela lagoon, Salada y del Burro, Chis Chis, La Tablilla, Las Encadenadas, and Las Barrancas (Geographical names according to Google Earth (2020). These are known locally as "the chain system" which in turn are an important weekend getaway destination for urbanites, who go there to fish, boat, camp, etc. As a result, there is significant human impact.

However, it is thanks to this ease of accessibility that we decided to begin our search for Utricularia platensis in these wetlands.

\section{The discovery}

In the month of February 2017, we took advantage of our summer vacations to begin our exploration of this area. First, we headed out towards an area of flooded terrain along the edge of the Chascomús lagoon (Fig. 2). However, due to a strong storm the previous night, the water was too deep and we didn't get very far, bringing our spirits down as we turned back. It wasn't a total loss though, since on the way back we stumbled across a flowering specimen of Ibicella lutea (Lindl.) V. Eselt (Martyniaceae) (Fig. 3)! I had been eagerly hoping to see this "protocarnivore" for a long time, and it gave us encouragement to continue exploring.

We slowly circled around the Chascomús lagoon, descending to the shore whenever we could to check among the reeds. This normally happened where a bridge crossed a stream or where a channel flowed into the lagoon. Finally, growing among reeds (Juncus sp., Juncaceae) and Hydrocotyle bonariensis Lam. (Araliaceae) along one channel, we found flowerless floating stems of an aquatic Utricularia, up to $\sim 25 \mathrm{~cm}$ in length. Could this be $U$. platensis? Or maybe it was another aquatic species such as $U$. breviscapa Wright ex Griseb. or U. foliosa L?

We continued exploring along the shore of the channel to the mouth of the lagoon, but as we got closer, we found progressively fewer and smaller Utricularia stems, some as short as $5 \mathrm{~cm}$. Sadly, they were sometimes seen floating alongside glass bottles, cardboard waste, pieces of plastic, and aluminum cans.

In order to identify the plants, we collected a few stems which we later compared with the descriptions and illustrations in Taylor's monograph. He mentions as a key characteristic of

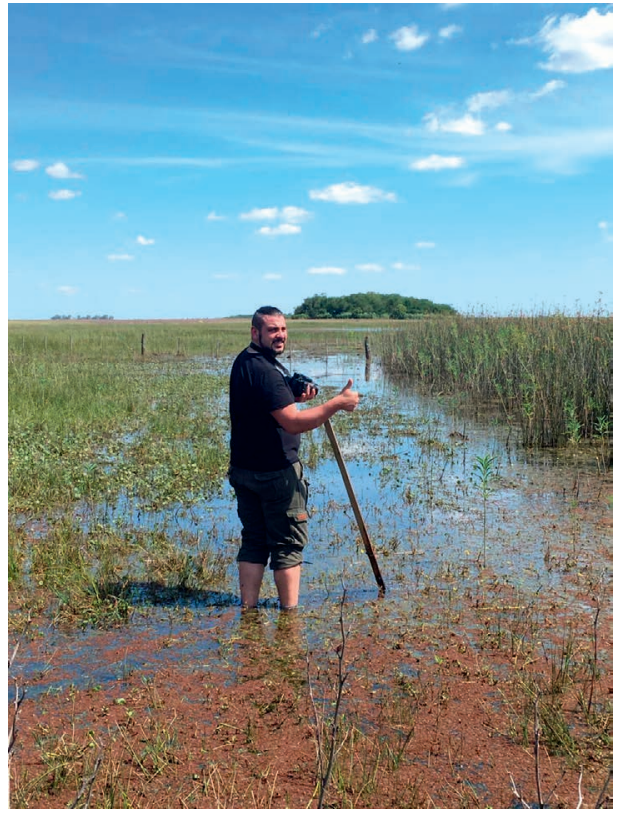

Figure 2: The author in flooded terrain along the edge of the Chascomús lagoon.

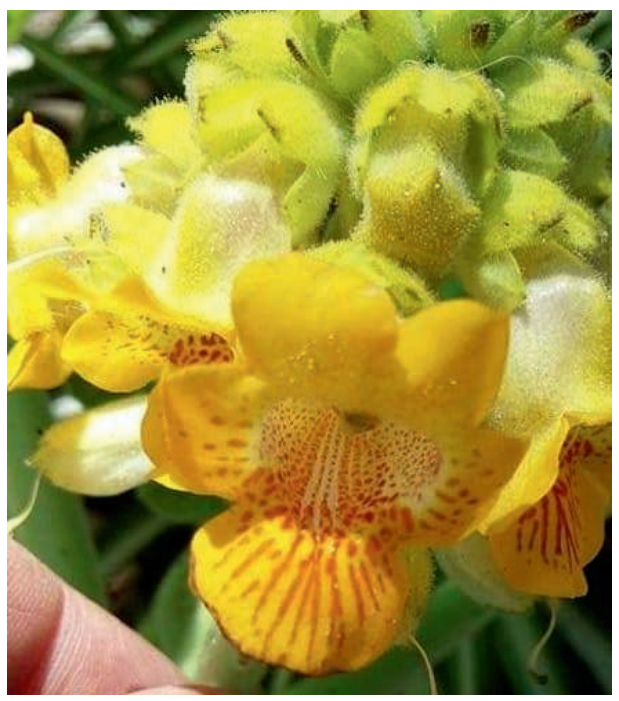

Figure 3: Ibicella lutea flower. 

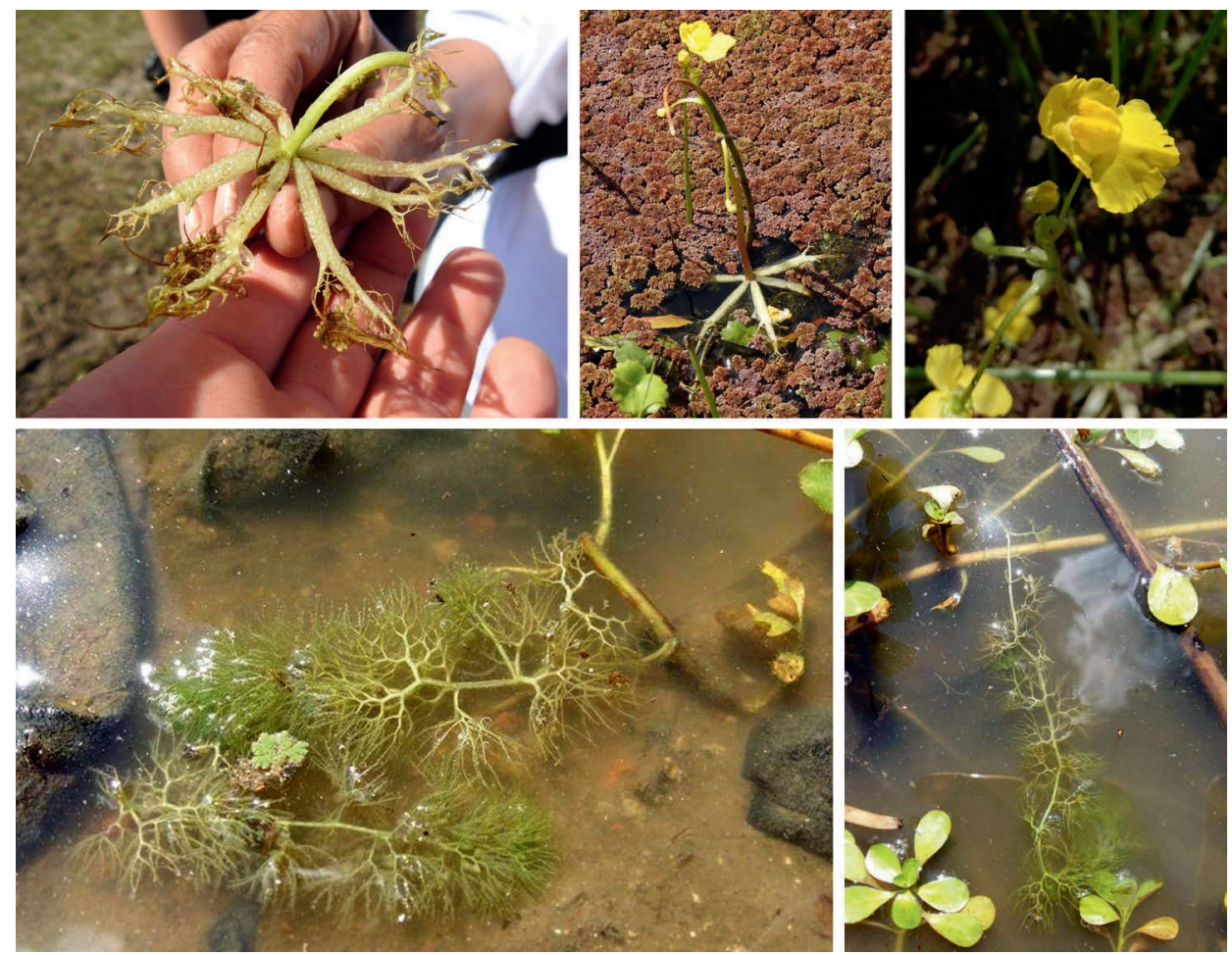

Figure 4: Utricularia platensis plant, flower, and stolons.

U. platensis that traps are “...inserted in or very near the angle between the [leaf] segments" (Taylor 1989). Looking at our plants, we could indeed see this characteristic ... we had rediscovered U. platensis (Fig. 4)!

Now we needed to find some in flower. According to the bibliography, U. platensis was known to flower towards the end of the year, in our Spring and early Summer (Taylor 1989). So finally, in November 2018, we were able to return to further explore the same lagoons, now with two more members in our group, and with a vehicle to help us cover more ground. Once again, we found small fragments of $U$. platensis stolons in almost all the streams and small tributaries of the Chascomús lagoon. But sadly, no flowers anywhere.

After exploring that area, we headed back to the car and drove a little further along the road that circles the lagoon. We decided to explore down a slope leading to a flooded shoreline, populated by reeds and Azolla filiculoides Lam. (Salviniaceae) (Fig. 2). Here, to our immense surprise and joy, we found a large and dense population of $U$. platensis, covering tens of square meters. The stolons were both floating (in water up to $50 \mathrm{~cm}$ deep) as well as growing on wet soil closer to the shore. Best of all, there were dozens of inflorescences too! The flowers of $U$. platensis are yellow and the scapes have a characteristic floating structure shaped like a wheel, with 7-9 vertices (morphologically similar to those seen in the closely related species $U$. breviscapa, U. inflata Walter, and $U$. radiata Small).

To further understand the ecology and life cycle of $U$. platensis, we returned to this region during autumn, in March 2020. Not a single trace of the plants was found, raising the question of whether 
they grow as annuals or perennials. Taylor mentions that small tubers have been observed at the apex of stolon branches, suggesting a possible means of surviving chilly winters beneath the mud.

Acknowledgements: To Belén Arce and Sandra Mantoani for helping to explore for U. platensis and also to Jano Nehuén Procopio, student and teaching assistant at the National University of La Plata (UNLP), who also accompanied us and helped identify all the plants seen in situ.

\section{References}

Dawson, G. 1965. Las Plantas Carnívoras. Buenos Aires: Libros del caminante.

Google Earth. 2020. https://www.google.com/earth/

Ministerio de Ciencia, Tecnología e Innovación. 2016. Bioeconomia Argentina.

http://www.cursobioeconomia.mincyt.gob.ar/proyectos-cofecyt/

Mulvany, S., Canciani, M., Safontas, M.P., Tangorra, M., Sahade, E., and Actis, T.S. 2019. Inventario de Humedales de la Provincia de Buenos Aires; Sistemas de Paisajes de Humedales; Primer Informe: Aspectos metodológicos, identificación y delimitación- 1st ed. - Gobierno de la Provincia de Buenos Aires. La Plata. http://www.opds.gba.gov.ar/imagenes/HUMEDALES.pdf

Taylor, P. 1989. The Genus Utricularia - A Taxonomic Monograph. London: Her Majesty's Stationery Office.

Velázquez, G.Á., Tisnés, A., and Gómez, N.J. 2014. Región pampeana: Geografía y bienestar según subregiones (2010). Geograficando 10(2). http://www.geograficando.fahce.unlp.edu.ar/article/ view/Geov10n02a09

World Wildlife Fund. 2021 Southern South America: Eastern Argentina. https://www.worldwildlife. org/ecoregions/nt0803. Accessed 15 February 2021.

Zuloaga, F.O. 1996. Catálogo de las plantas vasculares de la República Argentina. Missouri Botanical Garden.

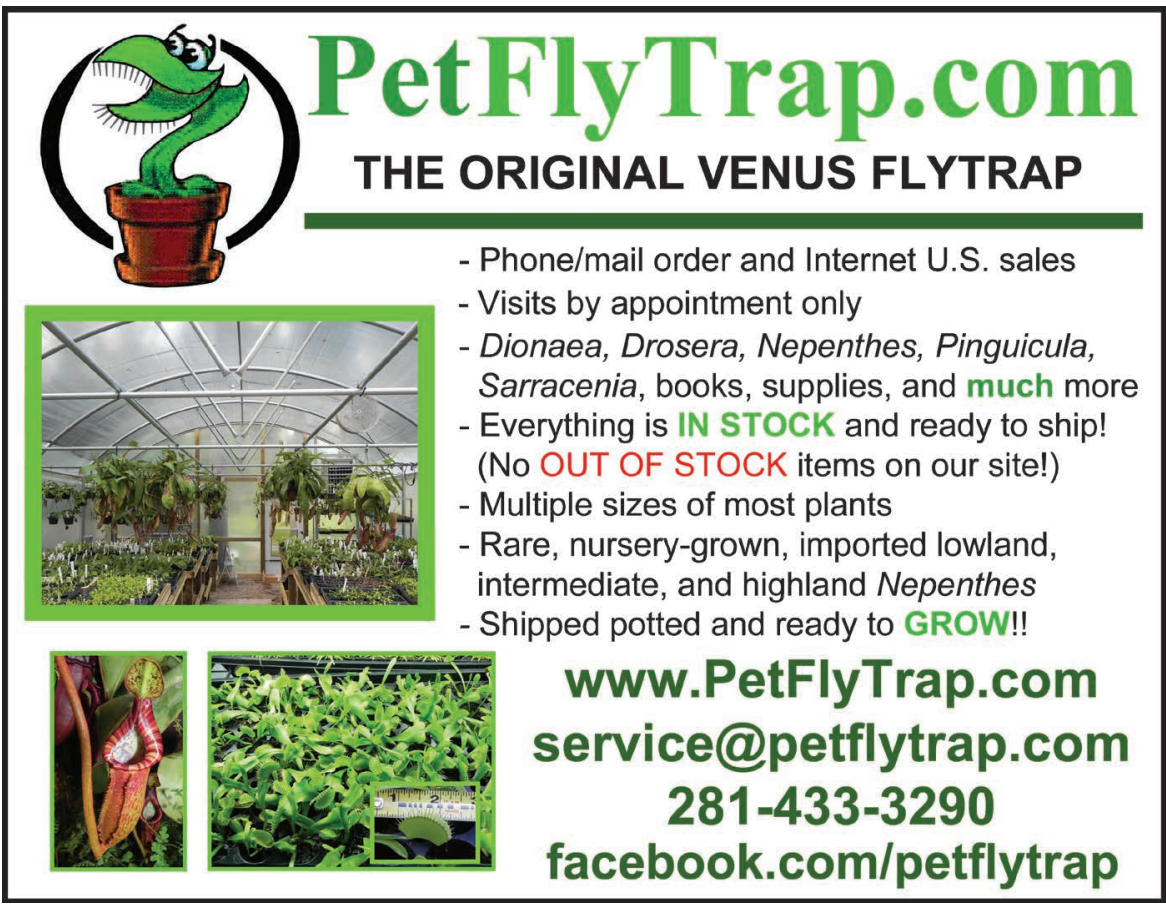

